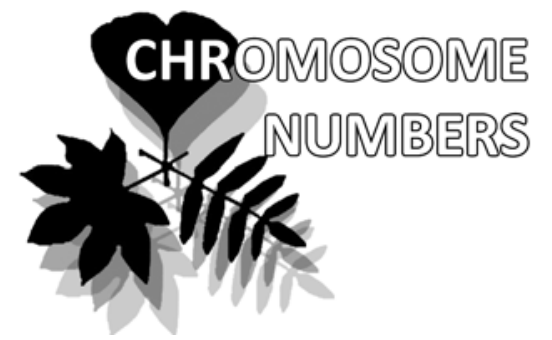

\title{
Chromosome numbers of some species of Artemisia L. from Altai region, South Siberia
}

\author{
Alexandr A. Korobkov ${ }^{1 *}$, Violetta V. Kotseruba ${ }^{1}$, Nina S. Probatova ${ }^{2}$
}

Alexandr A. Korobkov ${ }^{1 *}$

e-mail: stereodon@yandex.ru

Violetta V. Kotseruba ${ }^{1}$

e-mail: viola.kotseruba@gmail.com

Nina S. Probatova ${ }^{2}$

e-mail: probatova@ibss.dvo.ru

${ }^{1}$ V.L. Komarov Botanical Institute RAS, Saint-Petersburg, Russia

${ }^{2}$ Institute of Biology \& Soil Science FEB RAS, Vladivostok, Russia

* author for correspondence

Manuscript received: 11.12.2013

Review completed: 10.01.2014

Accepted for publication: 14.02.2014

\begin{abstract}
A B S T R A C T
Chromosome numbers for 14 species of Artemisia L. (Asteraceae) from the Altai region (South Siberia) are reported. One species - Artemisia compacta Fisch. ex DC. is studied caryologically for the first time. For 11 species there are first chromosome counts from Altai.
\end{abstract}

Keywords

chromosome numbers, Artemisia, Asteraceae, vascular plants, Altai region, South Siberia, Russia

\section{P E 3 Ю M E}

Коробков А.А., Коцеруба В.В., Пробатова Н.С.. Числа хромосом некоторых видов рода Artemisia L. с Аیтая, Южная Сибирь

Сообщаются числа хромосом Аля 14 вилов сосудистых растений из Алтайского региона Сибири. А^я Artemisia compacta Fisch. ex DC. приводятся первые данные по числу хромосом. На Алтае впервые исследованы 11 видов.

Ключевые слова

числа хромосом, Artemisia, Asteraceae, сосудистые растения, Алтайский регион, Южная Сибирь, Россия
This paper continues the series of contributions to chromosome numbers $(\mathrm{CN})$ study on Artemisia species in the flora of the Russian Federation (Korobkov et al. 2012a, 2012b, 2013; Probatova et al. 2008a, 2008b, 2010; Krivenko et al. 2013 etc.). Plants for this study were collected in the Altaiskii Krai and the Repubic of Altai. Figure 1 shows the locations of data sampling points within this area.

An asterisk $(*)$ before the species name indicates the first chromosome count for the species, (!) - first report from Altai region. Plants were collected mostly by A.A. Korobkov, who wrote comments as well. Chromosome counting was made by V.V. Kotseruba, English translation - by N.S. Probatova. Vouchers are deposited in LE (but some specimens - in ALTB).

\section{1. (!) Artemisia abrotanum L., $2 \mathrm{n}=18$.}

Russia, Altaiskii Krai, Loktevskii Raion, low shore of a salt lake, 2 Oct 1999, Korobkov 99-65: 40 (here and after: the nomber in bold after the sample code is the location point number shown on Fig. 1); Russia, Altaiskii Krai, Khabarskii Raion, near Khabary settlement, open birchwood, 6 Oct 1999, Korobkov 99-66: 48; Russia, Altaiskii Krai, Loktevskii Raion, the highway Staroaleisk - Gornyak, the terrace of Solonovka River, near the bridge, 2 Oct 1999, Korobkov 99-67: 38.

Distribution: Eurasia. The steppe and forest-steppe species. In the Altaiskii Krai, it occurs mostly along the lakesides of saline lakes and in river valleys, as well as in birchwoods and ditches on roadsides. The diploid CN $2 n=18$, that was revealed in plants from Altai, is the most common within the whole area of species distribution. The tetraploid CN 2n = 36 was found once in Poland (Kreitschitz \& Valles 2003). In European Russia 2n = 36 also exists in A. abrotanum, besides the common is diploid CN (it was found in Volga Region: two localities in Volgogradskaya Oblast') as well as $2 \mathrm{n}=54(6 \mathrm{x})$ - in Samarskaya Oblast'. In the Novgorodskaya Oblast' we found $2 \mathrm{n}=18+4 \mathrm{~B}$ (unpublished data).

\section{2. (!) Artemisia commutata Besser, $2 \mathrm{n}=36$.}

Russia, Republic of Altai, Chemal'skii Raion, the left bank of the Katun' River, $20 \mathrm{~km}$ W of Edigan settlement, high terrace, the foot of the SW slope, rubbly placer, forb steppe community, 3 Oct 2009, Korobkov 10-38: 25; Russia, Republic of Altai, Chemal'skii Raion, the valley of the Katun' River, near Chemal settlement, melkozem placer on the steep riverside slope, 3 Oct 2009, Korobkov 10-40: 28; Russia, Altaiskii Krai, Burlinskii Raion, the basin of the Burlinskoe Lake, Pinus and Betula forest, at the roadside, 7 Oct 1999, Korobkov 99-99: 47; Russia, Altaiskii Krai, Barnaul city, Yuzhnyi settlement, sandy hillock, at the edge of Pinus forest, 19 Sep 1999, Korobkov 99-100, 99-101, 99-130: 32; Russia, Altaiskii Krai, Zmeyinogorskii Raion, the shore of the Kolyvanovskoe Lake, stony hillock, 1 Oct 1999, Korobkov 99-102, 99-106: 36; Russia, Altaiskii Krai, Barnaul city, Yuzhnyi settlement, Pinus forest, roadside, 10 Oct 2009, Korobkov 10-41, 10-42: 32.

Distribution: Asia. The steppe and forest-steppe species. It is widely distributed in Altaiskii Krai and in the north of 
Korobkov et al.

Figure 1 Study area. Black circles and numbers from 01 to 51 are the sampling plot locations

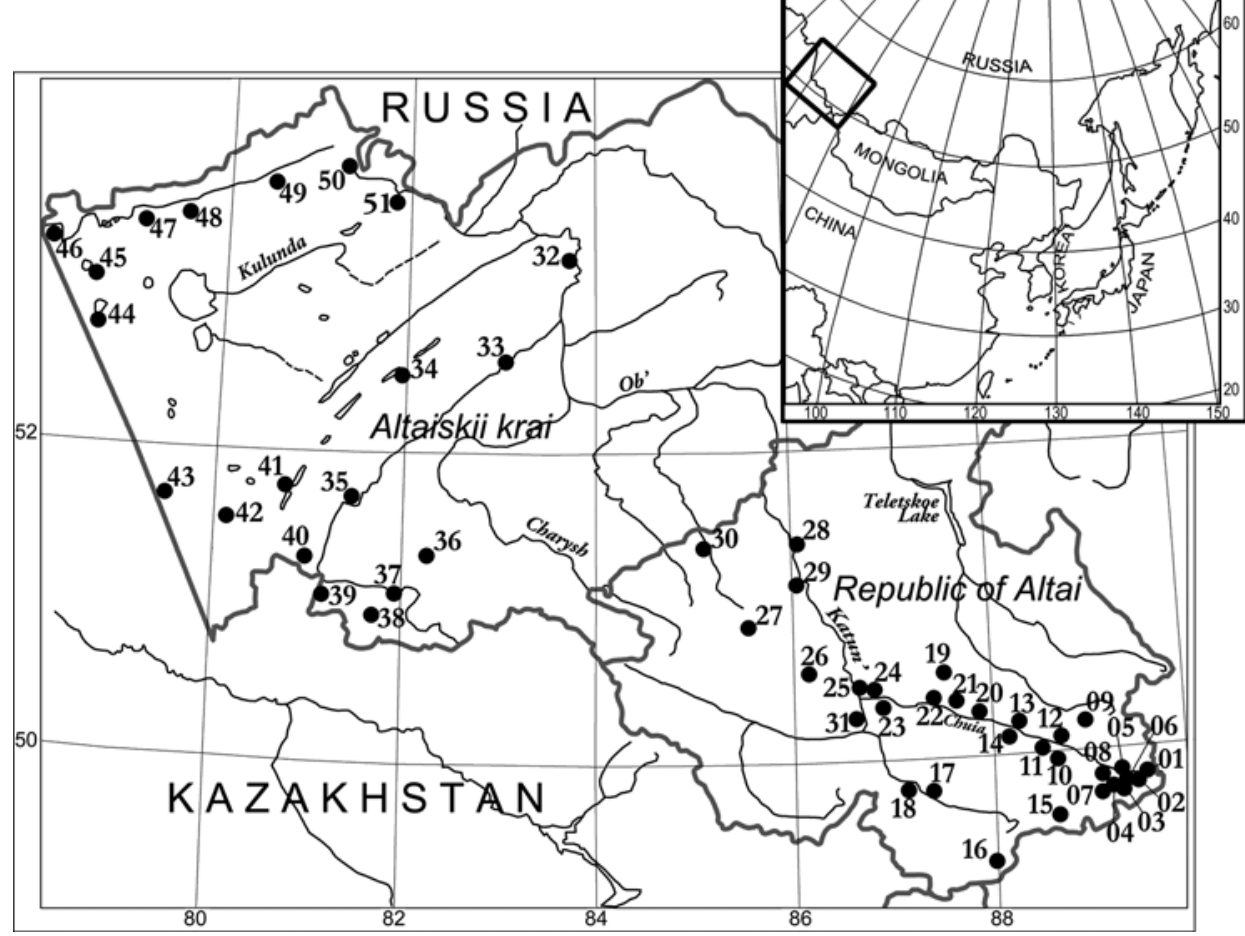

Republic of Altai, where it occurs in steppes, saline meadows, pine forests, birchwoods and on pebbles. Here the tetraploid $\mathrm{CN} 2 \mathrm{n}=36$, which is common throughout the whole area of the species distribution, occurs (Kawatani $\&$ Ohno 1964; Agapova et al. 1990; Malakhova 1990; Malakhova \& Markova 1994; Stepanov 1994; Samoilova 1990). In the Republic of Tyva, East Siberia and Mongolia, besides $2 \mathrm{n}=36$, the diploid CN 2n = 18 occurs (Hu et al. 1991; Pellicer et al. 2010; Korobkov et al. 2013). The significant morphological variability becomes apparent in this species by one and the same way in $2 \mathrm{x}$ and $4 \mathrm{x}$ populations, this allows us to consider such forms as ecological races. The most closely related to $A$. commutata is $A$. dolosa Krasch., the Altai high-mountain species.

\section{3. ${ }^{*}$ Artemisia compacta Fisch. ex DC., $2 \mathrm{n}=18$.}

Russia, Republic of Altai, Kosh-Agachskii Raion, in vicinity of Tashanta, 19 Aug 1998, Shmakov, German, Antoniuk 99-56 (ALTB): 07; Russia, Republic of Altai, KoshAgachskii Raion, right riverside of the Chegan-Uzun River, above Chegan-Uzun settlement, outcrops of speckled rocks, 22 Sep 1999, Korobkov 99-74, 99-75, 99-76: 13.

Distribution: Kazakhstan-South Siberia-North Mongolia. The desert and steppe petrophyte. It has a fragment of its area of distribution in high mountains of the SE Altai. The species occurs on saline soils of the slopes to lake depressions and on riversides in rocky steppes. The $\mathrm{CN}$ count was made in $A$. compacta for the first time.

\section{4. (!) Artemisia dolosa Krasch., 2n = 18.}

Russia, Republic of Altai, Kosh-Agachskii Raion, between Ortolyk and Mukhor-Tarkhota villages, 18 Aug 1999, Kuprianov 99-54 (ALTB): 10; Russia, Republic of Altai, Kosh-Agachskii Raion, the upper course of the Kokorya River, a slope with steppe vegetation, 19 Sep 1999, Kuprianov 99-55 (ALTB): 09; Russia, Republic of Altai, Ulaganskii Raion, the upper course of the Saryachik River, the riverside slope with steppe vegetation, 24 Sep 1999, Korobkov 99-90, 99-91: 19; Russia, Republic of Altai, Ulaganskii Raion, near Chibit settlement, rubbly slope of a hillock, 21 Sep 1999, Korobkov 99-92, 99-93: 22; Russia, Republic of Altai, Ongudaiskii Raion, the mouth of Chuya River, right riverside, rubbly slope, 25 Sep 1999, Korobkov 99-94: 25; Russia, Republic of Altai, Kosh-Agachskii Raion, Chuiskaya steppe, the Yustyt River, SW of Kokorya settlement, the riverside alkaline meadow, 27 Aug 2006, Dyachenko \& Shalimov 10-03 (ALTB): 08.

Distribution: Siberia-Mongolia. In the Republic of Altai the species is distributed in south high-mountain areas, it occurs in rocky steppes, open Larix forests near the upper limit of the forest belt, on flood-plain pebbles. Earlier, CNs $2 \mathrm{n}=18$ and $2 \mathrm{n}=36$ were known in plants from Mongolia (Garsia et al. 2006) and from Republic of Tyva, East Siberia (Korobkov et al. 2013).

This is the first $\mathrm{CN}$ report from plants of Altai.

\section{5. (!) Artemisia frigida Willd., 2n = 18 .}

Russia, Republic of Altai, Chemal'skii Raion, the valley of the Katun' River, near Chemal settlement, steep stony slope, Larix forest with shrubs, on rocks, 3 Oct 2009, Korobkov 10-22: 28; Russia, Republic of Altai, Chemal'skii Raion, $20 \mathrm{~km} \mathrm{~W}$ of Edigan settlement, the left bank of the Katun' River, near the bridge, the bottom of rocky slope, 4 Oct 2009, Korobkov 10-23: 29; Russia, Altaiskii Krai, Mikhailovskii Raion, near Rakity settlement, the edge of the light Pinus forest, the old fallow land, 4 Oct 1999, Ko- 
robkov 99-156, 99-159: 42; Russia, Altaiskii Krai, Loktevskii Raion, in vicinity of Noven'koe settlement, the shore of saline lake, high sandy hillocks, Artemisia community with grasses, 2 Oct 1999, Korobkov 99-157, 99-206: 39; Russia, Altaiskii Krai, Loktevskii Raion, the highway Staroaleysk - Gornyak, near the bridge on Solonovka River, steppe on the plain, 2 Oct 1999, Korobkov 99-207, 99-208: 38; Russia, Altaiskii Krai, Mikhailovskii Raion, the lakeside of the saline lake Gornostaevo, near Nevodnoe settlement, the clearing in Pinus forest, meadow community, 4 Oct 1999, Korobkov 99-210: 43.

\section{$-2 \mathrm{n}=36$.}

Russia, Republic of Altai, Kosh-Agachskii Raion, 34 $\mathrm{km}$ SE of Kosh-Agach settlement, Chuiskaya steppe, 22 Aug 1998, Shmakov, German, Antoniuk 99-45 (ALTB): 12; Russia, Republic of Altai, Kosh-Agachskii Raion, right riverside of Chuya River, $5 \mathrm{~km}$ above Chegan-Uzun settlement, outcrops of speckled rocks, the rubbly-melkozem top of a hillock, 22 Sep 1999, Korobkov 99-152, 99-205: 13; Russia, Republic of Altai, Ongudaiskii Raion, the right side of Chuya River, near the mouth, rubbly slope of a depression near the highway, 26 Sep 1999, Korobkov 99153: 25; Russia, Republic of Altai, Ulaganskii Raion, right riverside of the Chuya River, near Chibit settlement, hilly terrace, the grass and forb steppe, 21 Sep 1999, Korobkov 99-154: 22; Russia, Altaiskii Krai, Burlinskii Raion, the lake Bol'shoe Topol'noe (saline), $S$ sandy lakeside, the dry slope of a terrace, 6 Oct 1999, Korobkov 99-151: 46; Russia, Altaiskii Krai, Krutichinskii Raion, W lakeside of the Obskoe reservoir, in vicinity of Zakovryashino settlement, on loamy steep, 7 Oct 1999, Korobkov 99-155: 50; Russia, Altaiskii Krai, Slavgorodskii Raion, W lakeside of the lake Burlinskoe (saline), near Slavgorod town, flat slope to the lake, 5 Oct 1999, Korobkov 99-158, 99-204: 45; Russia, Altaiskii Krai, Slavgorodskii Raion, W lakeside of the lake Bol'shoe Yarovoe (bitter-saline), flat plain with hillocks, Artemisia community with grasses, 5 Oct 1999, Korobkov 99-209: 44.

Distribution: Eurasia-North America. The steppe petrophyte, widely distributed in steppes, on rocky slopes, in open pine and deciduous small-leaved forests, in flat and mountain areas throughout Altai region. In Altai region the species is represented both by diploid $(2 \mathrm{n}=18)$ and tetraploid $(2 \mathrm{n}=36)$ cytotypes, which also occur in the wide transcontinental area of this species. As a whole, the most common are diploid plants. In Canada (Manitoba) di- and tetraploid $\mathrm{CNs}$ were revealed once in the same root tip (Stathevitch \& Wojtas 1988). In Siberia, the highest diversity of cytotypes within $A$. frigida was revealed in Baikal region, where $2 \mathrm{x}, 4 \mathrm{x}$, and rarely $-6 \mathrm{x}$ plants occur (Belyaeva \& Siplivinsky 1977; Mendelak \& Schweitzer 1986; Pellicer et al. 2010).

\section{6. (!) Artemisia glauca Pall. ex Willd., $2 \mathrm{n}=18$.}

Russia, Republic of Altai, Kosh-Agachskii Raion, left riverside of the Yustyt River, at Sozontu Pass, 21 Aug 1998, Shmakov, German, Antoniuk 99-51 (ALTB): 06; Russia, Republic of Altai, Kosh-Agachskii Raion, in vicinity of Tashanta village, 19 Aug 1998, Shmakov, German, Antoniuk
99-52 (ALTB): 07; Russia, Republic of Altai, Kosh-Agachskii Raion, right riverside of the Chuya River, above CheganUzun settlement, on the slope of depression, 22 Sep 1999, Korobkov 99-123: 13; Russia, Republic of Altai, KoshAgachskii Raion, 810th km of Chuiskii road, right riverside of the Yustyt River, along the riverside, 16 Aug 2010, Gnutikov 11-18: 04; Russia, Republic of Altai, Kosh-Agachskii Raion, near the lake Malye Boguty, $2500 \mathrm{~m}$, on the gravel, 16 Aug 2011, Gnutikov 2013-66: 03; Russia, Republic of Altai, Kosh-Agachskii Raion, the riverside of the Naryn-Gol River, 2485 m, on moist ground, 18 Aug 2011, Gnutikov 2013-67: 01; Russia, Republic of Altai, Kosh-Agachskii Raion, the lake Kindykty-Kul', 2485 m, 18 Aug 2011, Gnutikov 2013-68: 02; Russia, Altaiskii Krai, Slavgorodskii Raion, in vicinity of Slavgorod town, 5 Oct 1999, Korobkov 99-122: 44; Russia, Altaiskii Krai, Aleiskii Raion, 30 km NE of Aleisk town, along the highway to Barnaul city, the valley of a stream, forb steppe community, 30 Sep 1999, Korobkov 99-124: 33; Russia, Altaiskii Krai, Khabarskii Raion, near Khabary settlement, light birchwood, 6 Oct 1999, Korobkov 99-125: 48; Russia, Altaiskii Krai, Burlinskii Raion, the lake Bol'shoe Topol'noe, S sandy lakeside, 6 Oct 1999, Korobkov 99-126: 46.

$-2 \mathrm{n}=36$.

Russia, Altaiskii Krai, Barnaul city, near Yuzhnyi settlement, the edge of Pinus forest, meadow community, 10 Oct 2009, Korobkov 10-35: 32.

Distribution: Eurasia (adventive in North America). The steppe and forest-steppe species. It can be found in steppes, meadow-steppe communities, on slopes of the river valleys, at the edges of open birchwoods and pine forests, expanding on the old fallow lands, and along the forest shelter belts. It is common both on plain and mountain areas of Altai region. In Altai and throughout the whole area of distribution of A. glauca the diploid $(2 \mathrm{n}=18)$ cytotype mainly occurs. The tetraploid cytotype of A. glauca $(2 \mathrm{n}=36)$ was collected once near Barnaul city, it was also found in the Omskaya Oblast' (Samoilova 1999) and in Republic of Tyva (Korobkov et al. 2013). V.P. Amel'chenko (1973) reported for A. glauca $2 \mathrm{n}=$ 16, 18, 32 from Tyva and Krasnoyarskii Krai (East Siberia).

\section{7. (!) Artemisia laciniata Willd., 2n = 18.}

Russia, Republic of Altai, Kosh-Agachskii Raion, the Dzhazator River, in vicinity of Bel'ashi village, sandy steppe, 20 Aug 1999, Kuprianov 99-35 (ALTB): 17; Russia, Republic of Altai, Ulaganskii Raion, right riverside of the Chuya River, near Chibit settlement, hilly terrace, the flat slope of depression, grass and forb meadow with shrubs, 21 Sep 1999, Korobkov 99-187, 99-188: 22; Russia, Republic of Altai, Ulaganskii Raion, the highway Aktash Ust'-Ulagan, the upper course of the Sary-Achik River, the bottom of S slope of a terrace, among shrubs, 24 Sep 1999, Korobkov 99-189, 99-194, 99-195: 21; Russia, Republic of Altai, Shebalinskii Raion, Anuyskii Range, the riverside of the Kurzun River, near its confluence with Peschanaya River, mixed forest, forb meadow, 3 Sep 2006, Dyachenko \& Shalimov 10-02 (ALTB): 30; Russia, Republic of Altai, Ongudaiskii Raion, middle course of the Ursul River, $3 \mathrm{~km}$ W of Ten'ga settlement, Larix forest, 1 Sep 2006, Dyachenko \& Shalimov 10-05 (ALTB): 27; Russia, Altaiskii Krai, 
Aleiskii Raion, in vicinity of the lake Monastyrskoe, 1 Sep 1998, Shmakov \& Tikhonov 99-34 (ALTB): 34; Russia, Altaiskii Krai, Pankrushikhinskii Raion, near Konevo settlement, the valley of the Burly River, Pinus and Betula forest, clearing, 7 Oct 1999, Korobkov 99-190: 49.

Distribution: South Siberia-Far East. The forest-steppe species. This is a common species in the plain and mountain areas of Altai region. It can be found in steppes, saline meadows, in light small-leaved forests, among shrubs, on pebbles. In its whole area of distribution the species is represented only by diploid cytotype $(2 \mathrm{n}=18)$. Indications of $2 n=54$ (Korobkov 1972, 1981) are the results of plants misidentifications (see Agapova et al. 1990). In high mountains of SE Altai $A$. laciniata is replaced by $A$. phaeolepis Krasch., the closely related polyploid species.

8. (!) Artemisia leucophylla (Turcz. ex Besser) Pamp., $2 \mathbf{n}=16$.

Russia, Republic of Altai, Ulaganskii Raion, near Kurai settlement, the slope of a hill, on dry pebbles of a stream, 23 Sep 1999, Korobkov 99-84, 99-226: 20; Russia, Republic of Altai, Ulaganskii Raion, near Aktash settlement, on the roadside rubble, 25 Sep 1999, Korobkov 99-85: 21; Russia, Republic of Altai, Kosh-Agachskii Raion, 810-th km of the Chuiskii road, left riverside of the Yustyt River, on the moist bank, 17 Aug 2010, Gnutikov 11-14: 04; Russia, Republic of Altai, Kosh-Agachskii Raion, the riverside of the Yustyt River, $2230 \mathrm{~m}$ alt., on the rocks, 20 Aug 2011, Gnutikov 201369: 04; Russia, Republic of Altai, Kosh-Agachskii Raion, the riverside of Burgazy River, $2000 \mathrm{~m}$ alt., the slope with steppe vegetation, 16 Aug 2011, Gnutikov 2013-70: 05.

Distribution: East Europe, Asia. The forest species. In the high-mountain areas of SE Altai it can be found on river pebbles, rocks, rubbly placer at the bottom of the rocks and along roadsides. In the Siberian part of its area of distribution the $\mathrm{CN} 2 \mathrm{n}=16$ often occurs, but sometimes the cytotypes with $2 \mathrm{n}=16+1 \mathrm{~B}$ and $2 \mathrm{n}=18$ were revealed (see Agapova et al. 1990).

9. Artemisia macrocephala Jacquem. ex Besser, 2n = 18 . Russia, Republic of Altai, Kosh-Agachskii Raion, Chuiskaya steppe, $34 \mathrm{~km}$ NE of Kosh-Agach settlement, 22 Aug 1998, Shmakov, German, Antoniuk 99-48 (ALTB): 12; Russia, Republic of Altai, Kosh-Agachskii Raion, near Tashanta village, 19 Aug 1998, Shmakov, German, Antoniuk 99-49 (ALTB): 07; Russia, Republic of Altai, Kosh-Agachskii Raion, right riverside of the Chegan-Uzun River, above the settlement Chegan-Uzun, rubbly plot in the flood-lands, pasture zone, 20 Sep 1999, Korobkov 99141: 13; Russia, Republic of Altai, Kosh-Agachskii Raion, the valley of Tarkhata River, above the frontier post, 24 Aug 2007, Smirnov \& Zubov 10-07 (ALTB): 10; Russia, Republic of Altai, Kosh-Agachskii Raion, 810-th km of the Chuiskii road, right riverside of the Yustyt River, on pebbly bank, 16 Aug 2010, Gnutikov 11-11: 04; Russia, Republic of Altai, Ust'-Koksinskii Raion, left riverside of the Koksu River, near its confluence with the Argut River, among shrubs on the stream bank, 28 Aug 2010, Gnutikov 11-12: 31; Russia, Republic of Altai, Kosh-Agachskii Raion, the riverside of Bar-Burgazy River, 2000 alt., slope with steppe vegetation, 16 Aug 2011, Gnutikov 2013-58: 05; Russia,
Republic of Altai, Kosh-Agachskii Raion, plateau Ukok, mountain range Tabyn-Bogdo-Ola, the riverside of the Severnaya Argamdzha River, 2233 m alt., 25 Aug 2011, Gnutikov 2013-61: 16; Russia, Republic of Altai, Ongudaiskii Raion, left riverside of the Bol'shoi Il'gumen' River, $910 \mathrm{~m}$ alt, on the rocks, 2 Sep 2011, Gnutikov 2013-63: 26.

Distribution: South Siberia - Mongolia - Central Asia. In high-mountain areas of SE Altai it grows on the screes, stony and sandy riversides, rubbly placer, at roadsides and in settlements. In Altai region the diploid race $(2 \mathrm{n}=18)$ occurs (Krasnikov \& Shirina 2006), the same is throughout the whole area of species distribution (Podlech \& Dieterle 1969; Amel'chenko 1979; Krogulevich \& Rostovtseva 1984; Astanova 1989; Garcia et al. 2006). The tetraploid $\mathrm{CN}$ was revealed only once, from Dushanbe city (Kawatani \& Ohno 1964). A. macrocephala is related to A. sieversiana Ehrh. ex Willd., A. jacutica Drob., A. samoiedorum Pamp., they are mostly Siberian, annual or perennial species.

10. (!) Artemisia marschalliana Spreng., $2 \mathrm{n}=36$.

Russia, Altaiskii Krai, Khabarskii Raion, near Khabary settlement, lakeside, 6 Oct 1999, Korobkov 99-104: 48; Russia, Altaiskii Krai, Egor'evskii Raion, S lakeside of the lake Gor'koe-Peresheyechnoe, sands at the edge of the Pinus forest, 3 Oct 1999, Korobkov 99-105: 41; Russia, Altaiskii Krai, Loktevskii Raion, in vicinity of Noven'koe settlement, the slope of sandy hillock, 2 Oct 1999, Korobkov 99-107: 39; Russia, Altaiskii Krai, Mikhailovskii Raion, near Rakity settlement, the plain, old fallow land, 4 Oct 1999, Korobkov 99-109: 42; Russia, Altaiskii Krai, Slavgorodskii Raion, flat slope to the lake Burlinskoe, 5 Oct 1999, Korobkov 99-110: 45.

Distribution: East Europe - South Siberia. The steppe and forest-steppe species. On flat left riversides of the Altaiskii Krai it occurs in dry stony steppes, pine forests, psammophyte communities, on slopes of the river valleys, and on the old fallow lands. The $\mathrm{CN}$ from Altai is reported here for the first time. The tetraploid cytotype $(2 \mathrm{n}=36)$ was known from Krasnoyarskii Krai (Amel'chenko 1979) and from Daghestan (Probatova et al. 2010). Besides, the diploid CN $(2 \mathrm{n}=18)$ is known within $A$. marschalliana, from Volgogradskaya Oblast' and from Kazakhstan (Pellicer et al. 2007; Probatova et al. 2010).

\section{1. (!) Artemisia pontica L., $2 \mathrm{n}=18$.}

Russia, Altaiskii Krai, Khabarskii Raion, near Khabary settlement, forb meadow in the light Betula forest, 6 Oct 1999, Korobkov 99-200: 48; Russia, Altaiskii Krai, Tretiakovskii Raion, $\mathrm{N}$ lakeside of the Guilëvskoe reservoir, near Korotaikha settlement, meadow at the edge of the forest shelter belt, 1 Oct 1999, Korobkov 99-201: 37; Russia, Altaiskii Krai, Aleiskii Raion, the highway Barnaul - Aleisk, $30 \mathrm{~km} \mathrm{NE}$ of Aleisk town, the valley of a stream, the grass and forb meadow-steppe community, 30 Sep 1999, Korobkov 99-202: 33.

Distribution: Europe - South Siberia. The steppe and forest-steppe species. In the Altaiskii Krai it grows in meadowsteppe, upland and saline meadows, in light birchwoods, at the edges of pine forests, on the old fallow lands. The diploid 
$\mathrm{CN}(2 \mathrm{n}=18)$ from Altai region is reported here for the first time, but the same $\mathrm{CN}$ was known for $A$. pontica in many localities of the species area of distribution (Kawatani \& Ohno 1964 ; Urbanska 1959; Kuzmanov et al. 1987; Mendelak \& Schweitzer 1986; Majovsky et al. 1987; Samoilova 1999; Probatova et al. 2010). A. pontica is adventive in North America (SE Canada), and there the CN 2n = 18 was also revealed (Morton 1981). From the Omskaya Oblast' (West Siberia) two CNs $-2 \mathrm{n}=18$ and 32 were reported (Samoilova 1999), but the last CN is doubtful.

12. (!) Artemisia scoparia Waldst. et Kit., $2 \mathrm{n}=16$.

Russia, Republic of Altai, Ongudaiskii Raion, right riverside of the Chuya River, near the mouth, rubbly hillocks at the riverside, 25 Sep 1999, Korobkov 99-113: 25; Russia, Republic of Altai, Chemalskii Raion, left riverside of the Katun' River, $20 \mathrm{~km} \mathrm{~W}$ of Edigan settlement, near the bridge, high terrace, forb steppe with Caragana, 3 Oct 2009, Korobkov 10-33: 29; Russia, Republic of Altai, Chemalskii Raion, the valley of Katun' River, in vicinity of Chemal settlement, roadside, forb meadow community, 3 Oct 2009, Korobkov 10-34: 28; Russia, Altaiskii Krai, Barnaul city, Yuzhnyi settlement, old fallow land at the edge of pine forest, 19 Sep 1999, Korobkov 99-111: 32; Russia, Altaiskii Krai, Khabarskii Raion, near Khabary settlement, flat slope of a hillock, at the edge of shrubs community, 6 Oct 1999, Korobkov 99-112: 48; Russia, Altaiskii Krai, Pospelikhinskii Raion, near Krasnoyarskoe settlement, sandy flood-land of the Alei River, 1 Oct 1999, Korobkov 99-114: 35.

\section{$-2 n=18$.}

Russia, Republic of Altai, Ongudaiskii Raion, left riverside of the Chuya River, the settlement Belyi Bom, $980 \mathrm{~m}$ alt., on rocks, 30 Aug 2010, Gnutikov 11-17: 23.

Distribution: Eurasia. The desert, steppe and forest-steppe species. In Altai region it occurs in floodplain meadows, light pine forests, at the field edges, in forest shelter belts, roadsides and settlements. Multiple CN counts (over 40) throughout the area of the species distribution revealed $2 \mathrm{n}=16(\mathrm{x}=8)$; however, sometimes 2n = 18 ( $\mathrm{x}=9$ ) occur (Mehra \& Remandan 1969; Yan et al. 1989; Qiao et al. 1990; Joohnson \& Brandham 1997). In Siberian plants of $A$. scoparia the CN $2 \mathrm{n}$ $=32$ was registered once (Amel'chenko 1979). Besides $2 \mathrm{n}=$ 16 , the cytotype with $2 \mathrm{n}=36$ was reported, from Liubl'ana (Kawatani \& Ohno 1964).

13. (!) Artemisia sieversiana Ehrh. ex Willd., $2 \mathrm{n}=18$. Russia, Republic of Altai, Ongudaiskii Raion, right riverside of the Chuya River, $10 \mathrm{~km}$ of its mouth, 19 Aug 1998, Shmakov, Antonyuk, German 99-41 (ALTB): 24; Russia, Republic of Altai, Ulaganskii Raion, right riverside of the Chuya River, near Chibit settlement, hilly terrace, shrubs community on the slope of depression, 21 Sep 1999, Korobkov 99-143: 22; Russia, Republic of Altai, Ongudaiskii Raion, right riverside of the Chuya River, near its mouth, rubbly slope of depression, 25 Sep 1999, Korobkov 99-144: 25; Russia, Altaiskii Krai, Barnaul city, Yuzhnyi settlement, the Barnaul forest experimental station, the belt Pinus and Betula forest, on the slope of sand-pit, 17 Sep 1999, Korobkov 99-142: 32; Russia, Altaiskii Krai, Aleiskii
Raion, the highway Barnaul - Aleisk, $30 \mathrm{~km} \mathrm{NE} \mathrm{of} \mathrm{Aleisk}$ town, the valley of a stream, the meadow-steppe vegetation, 30 Sep 1999, Korobkov 99-145: 33; Russia, Altaiskii Krai, Burlinskii Raion, the lake Bol'shoe Topol'noe, S sandy lakeside, 6 Oct 1999, Korobkov 99-146: 46.

Distribution: East Europe - Siberia - East Asia. Mainly steppe and forest-steppe species. In Altai region $A$. sieversiana occurs everywhere, in steppes, meadows, on shores, saline lands, old and latest fallow lands, at the field edges and roadsides. Actively expands on abandoned lands.

A. sieversiana belongs to the group of constant diploid $(2 \mathrm{n}=18)$ annual and perennial monocarpic spicies, with A. jacutica Drob. and A. macrocephala.

\section{4. (!) Artemisia vulgaris L., 2n = 16.}

Russia, Republic of Altai, Ulaganskii Raion, near Chibit settlement, at the roadside, 21 Sep 1999, Korobkov 99-86: 22; Russia, Republic of Altai, Chemal'skii Raion, left riverside of the Katun' River, $20 \mathrm{~km}$ W of Edigan settlement, near the bridge, high terrace, herb-bunchgrass steppe with Caragana, 3 Oct 2009, Korobkov 10-29, 10-31: 29; Russia, Republic of Altai, Kosh-Agachskii Raion, steppe Samakha, 1555 m alt., slide-rocks, 27 Aug 2010, Gnutikov 11-13: 18; Russia, Altaiskii Krai, Pospelikhinskii Raion, near Krasnoyarskoe settlement, the flood-land of the Alei River, the Populus and Salix open forest, 1 Oct 1999, Korobkov 99-87: 35; Russia, Altaiskii Krai, Barnaul city, Yuzhnyi settlement, the belt Pinus forest, at the roadside, 17 Sep 1999, Korobkov 99-88: 32; Russia, Altaiskii Krai, Kamenskii Raion, the bank of Kulundinskii canal, 7 Oct 1999, Korobkov 99-89: 51; Russia, Altaiskii Krai, Barnaul city, near Yuzhnyi settlement, Pinus forest, at the roadside, sparse forb community, 10 Oct 2009, Korobkov 10-30, 10-32: 32.

Distribution: Eurasia - North America. Multi-zonal ruderal species. In Altai it occurs at the forest edges, in forest shelter belts, among shrubs, on fallow lands, at the field edges, roadsides and settlements. The species occurs on areas with disturbed natural vegetation.

In Altai and throughout Russia the CN $2 \mathrm{n}=16(\mathrm{x}=8)$ constantly occurs, as well as in Europe and North America. Only one report of $2 \mathrm{n}=36$ is known from Belarus (Semerenko 1989), it seems to be doubtful. A. vulgaris is related to Siberian and Far East species with $2 \mathrm{n}=16-$ A. leucophylla, A. rubripes Nakai, $A$. sylvatica Maxim.

\section{ACKNOWLEDGEMENTS}

The authors are grateful to Colleagues from the South Siberian Botanical Garden of the Altaisky State University for their help in the field work, and to Alexandr A. Gnutikov (V.L. Komarov Botanical Institute RAS) for providing plant material from Gorny Altai.

The study was financially supported by the Russian Foundation for Basic Research - RFBR (grant 13-04-01468, to A.A. Korobkov). 


\section{LITERATURE CITED}

Agapova, N.D., K.B. Arkharova, L.I. Vakhtina, E.A. Zemskova \& L.V. Tarvis 1990. Chromosome numbers in flowering plants of the flora of the USSR: Aceraceae - Menyanthaceae. Nauka, Leningrad. 509 pp. (in Russian). [Агапова Н.А., Архарова К.Б., Вахтина А.И., Земскова Е.А., Тарвис А.В. 1990. Числа хромосом цветковых растений фморы СССР: семейства Aceraceae Menyanthaceae. $\Lambda .:$ Наука. 509 с.]

Amel'chenko, V.P. 1979. Contribution to study of Artemisia from Yenisei group. In: New data on the Siberian nature. Tomsk. P. 114 118 (in Russian) [Амельченко В.П. 1979. К изучению поАыней Приенисейской группы // Новые Аанные о природе Сибири. Томск. С. 114-118.].

Astanova, S.B. 1989. Chromosome numbers of representatives of the family Compositae in the Tadzhikistan flora. In: II Conference on plant caryology. Abstr. Novosibirsk. P. 8991 (in Russian) [Астанова С.Б. 1989. Хромосомные числа представителей семейства сложноцветных флоры Таджикистана // II Совещание по кариологии растений. Тез. Аокм. Новосибирск. 1989. С. 89-91.]

Belyaeva, V.A. \& V.N. Siplivinsky 1977. Chromosome num bers and taxonomy of some species of the Baikal flora. III. Botanicheskii Zhurnal 62 (8): 1132-1142 (in Russian). [Беляева И.А., Сипливинский В.Н. 1977. Хромосомные числа и таксономия некоторых видов Байкальской флоры. III // Ботанический журнал. Т. 62, № 8. С. 1132-1142.

Garcia, S., T. Garnatje, Sh. Dariimaa, S. Tsooj \& J. Valles 2006. New or rarely reported chromosome numbers in taxa of subtribe Artemisiinae (Anthemideae, Asteraceae) from Mongolia. Botanical Journal of the Linnean Society 150: 203-210.

Hu, T., R. Cao, Y. Wang \& S. Zhang 1991. Studies on chromosomes of five species of Artemisia in Nei Mongol. Acta Scientiarum Naturalium Universitatis Intramongolicae 22 (3): 422-427.

Johnson, M.A.T. \& P.E. Brandham 1997. New chromosome numbers in petaloid monocotyledons and in other miscellaneous angiosperms. Kew Bulletin 52 (1): 121-138.

Kawatani, T. \& T. Ohno 1964. Chromosome numbers in Artemis ia. Bulletin of National Institute of Hygienic Sciences 82: 183-193.

Korobkov, A.A. 1972. Contribution to cytotaxonomical characteristics of some species of Artemisia L. from the North-East of the U.S.S.R Botanicheskii Zhurnal 57 (10): 1316-1327 (in Russian). [Коробоков А.А. 1972. К цитотаксономической характеристике некоторых видов рода Artemisia L. Северо-Востока СССР / / Ботанический журнал. Т. 57, № 10. С. 1316-1327.]

Korobkov, A.A. 1981. Sages of the North-East of the U.S.S.R. Nauka, Leningrad, 120 p. (in Russian). [Коробков А. А. 1981. Полыни Северо-Востока СССР. А.: Наука. 120 c.]

Korobkov, A.A., V.V. Kotseruba, N.S. Probatova \& A.A. Gnutikov 2012a. IAPT/IOPB chromosome data 13 (K. Marhold, ed.) Taxon 61 (4): 895-896, E 21-27.

Korobkov, A.A., V.V. Kotseruba, N.S. Probatova, E.G. Rudyka \& A.A. Gnutikov 2012b. IAPT/IOPB chromosome data 14 (K. Marhold \& I. Breitwieser, eds.). Taxon 61 (6): 1339-1340, E 13-15.

Korobkov, A.A., V.V. Kotseruba, N.S. Probatova, A.V. Shatokhina \& E.G. Rudyka 2013. IAPT/IOPB chromosome data 14 (K. Marhold \& I. Breitwieser, eds.). Taxon 62 (5): 1075-1077, E 11-15.

Krasnikov, A.A. \& E.R. Schirina 2006. Chromosome numbers of some species of Artemisia (Asteraceae) from Siberia. Botanicheskii Zburnal 91 (3): 481-482 (in Russian). [Красников A.A., Ширина Е.Р. 2006. Хромосомные числа некоторых виАов Artemisia (Asteraceae) из Сибири // Ботанический журнац. T. 91, № 3. C. 481-482.]

Kreitschitz, A. \& J. Vallès 2003. New or rare data on chromosome numbers in several taxa of the genus Artemisia (Asteraceae) in Poland. Folia Geobotanica 38 (3): 333-343.

Krivenko, D.A., V.V. Kotseruba, S.G. Kazanovskii, A.V. Verkhozina \& O.D. Chernova. 2013. IAPT/IOPB chromosome data 16 (K. Marhold, ed.). Taxon 62 (6): 1356-1358, E 4-8.

Krogulevich, R.E. \& T.S. Rostovtseva 1984. Chromosome numbers of flowering plants of Siberia and Far East. Novosibirsk. 286 p. (in Russia). [Крогулевич Р.Е., Ростовцева Т.С. 1984. Хромосомные числа цветковых растений Сибири и Аальнего Востока. Новосибирск. 286 с.]

Kuzmanov, B.F., C.B. Georgieva \& V.A. Nikolaeva 1986. Chromosome numbers in Bulgarian flowering plants. 1. Asteraceae. Phytologia 31: 71-75 (in Bulgarian). [Кузманов, Б.А., Георгиева
С.Б., Николаева В.А. 1986. Хромозомни числа на бъелгарски цветни растения. 1. Asteraceae // Фитология 31: 71-75.]

Malakhova, L.A. 1990. Caryological analysis of nature populations of rare and endangered plants in the south of the Tomskaya Oblast'. Bulletin of the Main Botanical Garden 155: 60-66 (in Russian). [Малахова А.А. 1990. Кариологический анализ природных популяций редких и исчезающих растений на юге Томской области // Бюлметень ГАавного Ботанического саАа. Вып. 155. С. 60-66.].

Malakhova, L.A. \& G.A. Markova 1994. Chromosome numbers of flowering plants of the Tomskaya Oblast'. Dicotyledons. Botanicheskii Zhurnal 79 (12): 103-106 (in Russian). [Малахова А.А., Маркова Г.А. 1994. Числа хромосом цветковых растений Томской области. Авудольные // Ботанический журнал. Т. 79, № 12. С. 103-106.]

Májovsky, J., A. Murin a kolektiv 1987. Karyotaxonomický Prebl'ad flóry Slovenska. Bratislava. 436 pp. (in Slovenian).

Mehra, P.N. \& P. Remanandan 1969. IOPB chromosome number reports XXII (A. Löve \& D. Löve, ed.). Taxon 18 (3): 433-442.

Mendelak, M. \& D. Schweizer 1986. Giemza C-Banden kariotypes of some diploid Artemisia species. Plant Systematics and Evolution 152 (3-4): 195-210.

Morton, I.K. 1981. Chromosome numbers in Compositae from Canada and the U.S.A. Botanical Journal of the Linnean Society 82 (3): 357-368

Qiao, Y.M., X.X. Yan, S.Z. Zhangsz. 1990. A study of the chromosomes of 20 species of the genus Artemisia. Grassland of China 6: 24-31.

Pellicer, I., S. Garcia, T. Garnatje, Sh. Dariimaa, A.A. Korobkov \& J. Valles 2007. Chromosome numbers in some Artemisia (Asteraceae, Anthemideae) species and genome size variation in subgenus Dracunculus: karyological, systematic and phylogenetic implications. Chromosome Botany 2: 45-53.

Pelllicer, J., S. Garcia, M.A. Canela, T. Garnatje, A.A. Korobkov, J.D. Twibell \& J. Valles 2010. Genome size dynamics in Artemisia L. (Asteraceae): following the track of polyploidy. Plant Biology 12: 820-830

Podlech, D. \& A. Dieterle 1969. Chromosomenstudien an afganischen Pflanzen. Candollea 24 (2): 185-243.

Probatova, N.S., E.G. Rudyka, V.P. Seledets \& V.F. Nechaev 2008a. IAPT / IOPB chromosome data 6 (K. Marhold, ed.). Taxon 57 (4): 1268-1271, E4-12.

Probatova, N.S., V.P. Seledets \& E.G. Rudyka 2008b. IAPT / IOPB chromosome data 5 (K. Marhold, ed.). Taxon 57 (2): 558-562, E16-24

Probatova, N.S., A.A. Korobkov, A.A. Gnutikov, E.G. Rudyka, V.V. Kotseruba \& V.P. Seledets 2010. IAPT / IOPB chromosome data 10 (K. Marhold, ed.). Taxon 59 (6): 1935-1937.

Samoilova, G.V. 1999. Sages of the Omskaya Oblast' (geography, ecology, chemosystematics, chromosome numbers. Author's abstr. of $\mathrm{PhD}$ dissert. Novosibirsk. 16 p. (in Russian). [Самойлова Г.В. Полыни Омской области (география, экология, хемосистематика, хромосомные числа). Автореф. Аисс. .... канд. биол. наук. Новосибирск. 16 с.]

Semerenko, L.V.1989. Chromosome numbers of some representatives of the families Asteraceae, Fabaceae, Orchidaceae, Poaceae in the flora of the Berezinskii biosphere reserve (Belorussia). Botanicheskii Zhurnal 74 (11): 1671-1673 (in Russian). [Семеренко А.В. 1989. Хромосомные числа некоторых представителей семейств Asteraceae, Fabaceae, Orchidaceae, Poaceae фморы Березинского биосферного заповедника (БССР) // Ботанический журнал. Т. 74, № 11. С. 1671-1673.]

Skalinska, M., R. Czapik \& M. Piotrowicz 1959. Further studies in chromosome numbers of Polish Angiosperms (Dicotyledons). Acta Societatis Botanicorum Poloniae 28 (3): 487-529.

Stahevitch, A. \& W. Wojtas 1988. Chromosome numbers of some North American species of Artemisia (Asteraceae). Canadian Journal of Botany 66 (4): 672-676.

Stepanov, N.V. 1994. Chromosome numbers of some plants of the flora of Krasnoyarskii Krai. Botanicheskii Zhurnal 79 (2): 135-139 (in Russian). [Степанов Н.В. 1994. Числа хромосом некоторых растений фморы Красноярского края // Ботанический журнал. Т. 7, № 2. С. 135-139.]

Yan, X.X., S.Z. Zhang, J.F. Yan, Fu Xq \& L.Y. Wang 1989. Chromosome numbers and geographical distribution of 68 species of forage plants. Zhongguo Caoyuan [Grassland of China] 4: 53-60. 